Tropical Journal of Pharmaceutical Research September 2019; 18 (9): 1839-1844

ISSN: 1596-5996 (print); 1596-9827 (electronic)

(1) Pharmacotherapy Group, Faculty of Pharmacy, University of Benin, Benin City, 300001 Nigeria.

Available online at http://www.tjpr.org

Original Research Article

http://dx.doi.org/10.4314/tjpr.v18i9.8

\title{
Hypaconitine confers protection on ketamine-induced neuronal injury in neonatal rat brain via a mechanism involving $\mathrm{PI} 3 \mathrm{~K} / \mathrm{Akt} / \mathrm{Bcl}-2$ pathway
}

\author{
Junbao Liu, Yubo Hu, Linlin Li, Longyun Li* \\ Department of Anesthesiology, China-Japan Union Hospital of Jilin University, Changchun, Jilin 130033, China \\ ${ }^{*}$ For correspondence: Email: OscarqHarriswy@yahoo.com; Tel: 0086-431-84997222
}

Sent for review: 21 May 2018

Revised accepted: 23 August 2019

\begin{abstract}
Purpose: To investigate the neuroprotective effect of hypaconitine against ketamine-induced neuronal injury in the brains of neonatal rats, and the underlying mechanism of action.

Methods: Seven day-old Sprague-Dawley pups weighing 15.0 to $20.0 \mathrm{~g}$ (mean weight $=17.5 \pm 2.5 \mathrm{~g}$ ), and aged 7 days were used for this study. The pups were sacrificed, and their forebrains isolated and used to prepare cell suspensions. The isolated cells were treated with ketamine $(100 \mu \mathrm{M})$ or varied concentrations of hypaconitine $(0.1-2 \mu \mathrm{M})$ or LY294002 $(10 \mu \mathrm{M})$. The cells were trypsinized and cultured at $37{ }^{\circ} \mathrm{C}$ in $10 \%$ fetal bovine serum (FBS) supplemented Dulbecco's modified Eagle's medium (DMEM) in a humidified incubator containing $5 \% \mathrm{CO}_{2}$. Cell viability was determined using MTT assay, while TUNEL assay was used to determine the extent of apoptosis in the cells. The expressions of $p$ $A k t, B C l-2$ and caspase-3 were determined using Western blotting.

Results: There were only few viable cells in the ketamine-treated group, and cell viability was significantly and dose-dependently increased in hypaconitine-treated groups $(p<0.05)$. The extent of apoptosis was significantly higher in ketamine-treated cells than in control cells, but treatment with hypaconitine significantly reduced the number of apoptotic cells $(p<0.05)$. However, in the presence of LY294002 (a PI3K-specific inhibitor), the effect of hypaconitine on neuronal cell apoptosis was significantly reversed $(p<0.05)$. The expressions of $p$-Akt and $B c l-2$ were significantly down-regulated while the expression of caspase-3 was significantly upregulated in ketamine-treated neuronal cells, when compared with control group $(p<0.05)$. However, in cells treated with hypaconitine, the expressions of $p$-Akt and Bcl-2 were significantly upregulated, while the expression of caspase- 3 was significantly down-regulated $(p<0.05)$. Treatment of neuronal cells with hypaconitine in the presence of LY294002 significantly reversed the effect of hypaconitine on the expressions of p-Akt, Bcl-2 and caspase-3 $(p<0.05)$.

Conclusion: These results suggest that hypaconitine ameliorates ketamine-induced neuronal injury in neonatal rats via a mechanism involving the PI3K/Akt/Bcl-2 pathway.
\end{abstract}

Keywords: Hypaconitine, Anesthesia, Apoptosis, Neuroprotection, Expression

This is an Open Access article that uses a fund-ing model which does not charge readers or their institutions for access and distributed under the terms of the Creative Commons Attribution License (http://creativecommons.org/licenses/by/4.0) and the Budapest Open Access Initiative (http://www.budapestopenaccessinitiative.org/read), which permit unrestricted use, distribution, and reproduction in any medium, provided the original work is properly credited.

Tropical Journal of Pharmaceutical Research is indexed by Science Citation Index (SciSearch), Scopus, International Pharmaceutical Abstract, Chemical Abstracts, Embase, Index Copernicus, EBSCO, African Index Medicus, JournalSeek, Journal Citation Reports/Science Edition, Directory of Open Access Journals (DOAJ), African Journal Online, Bioline International, Open-J-Gate and Pharmacy Abstracts 


\section{INTRODUCTION}

Ketamine is a dissociative drug used clinically as an anesthetic in infants during surgical procedures [1]. It is an antagonist of noncompetitive N-methyl-D-aspartate (NMDA) receptor, and studies have shown that its use during surgeries causes neuronal injury in neonatal rats [2]. It induces apoptosis in neuronal cell culture in vitro [3]. Exposure of children below 4 years to ketamine causes emotional and behavioral disorders [4]. Ketamine-induced apoptosis is the commonest mechanism involved in neurodegeneration [5]. In neonates and pediatric patients, ketamine is used for the induction of anesthesia, but with a number of cautions. Thus protection against ketamineinduced neuronal injury is required in the development of alternative neuroprotective agents [6]. The past few decades saw the emergence of novel drugs from natural sources with potent neuroprotective effects against ketamine induced neuronal injury [7-9].

Aconite tuber is used in Traditional Chinese Medicine (TCM) as an analgesic, and also for treating cardiovascular dysfunction, neurological disorders, rheumatoid arthritis, fever, and as an analgesic [10-13]. This tuber contains several bioactive compounds such as hypaconitine, mesaconitine and aconitine, which are alkaloids reported to confer protection on the heart and central nervous system (CNS) [14-16]. Although these alkaloids are also toxic to some organs and tissues, hypaconitine is a less toxic analogue of aconitine and exhibits it good cardiotonic property [17]. The present study investigated the neuroprotective effect of hypaconitine against ketamine-induced neuronal injury in brains of neonatal rats, and the underlying mechanism.

\section{EXPERIMENTAL}

\section{Materials and reagents}

Sprague-Dawley pups were procured from Changzhou Cavens Laboratory Animal Co., Ltd. Microplate reader (ELX-800) was purchased from Bio-Tek Instruments (USA). Bicinchoninic acid (BCA) assay kit was a product of Sangon Biotech Co., Ltd., while chemiluminescence liquid and autoradiography film were purchased from Bio-Rad Laboratories Inc. (USA). Trizol reagent was a product of Thermo Fisher Scientific Inc. (USA).

\section{Experimental rats}

Sprague-Dawley pups weighing 15.0 to $20.0 \mathrm{~g}$ (mean weight $=17.5 \pm 2.5 \mathrm{~g}$ ), and aged 7 days were used for this study. The pups were maintained under standard conditions of care, and were exposed to $12 \mathrm{~h}$ light/dark cycles and maintained at $25{ }^{\circ} \mathrm{C}$ and $48 \%$ humidity. The study protocol was approved by The Institutional Animal Care and Use Committee of China-Japan Union Hospital of Jilin University, China (approval no. IACUC/C-JUH/JU/2017/05).

\section{Experimental design}

The Sprague-Dawley pups were sacrificed. Their forebrains were isolated and used for preparing cell suspensions. The cells were trypsinized and cultured at $37{ }^{\circ} \mathrm{C}$ in $10 \%$ FBS-supplemented Dulbecco's modified Eagle's medium (DMEM) in a humidified incubator containing $5 \% \mathrm{CO}_{2}$. After $48 \mathrm{~h}$ of incubation, the medium was replaced with neurobasal medium supplemented with B27. The medium was changed every two days until the cells attained $80 \%$ confluency.

\section{MTT assay}

Cell viability was determined using ation of cell viability. The cells at exponential growth phase were seeded at a density of $2 \times 10^{4}$ cells/well in 96-well plates containing DMEM. After $24 \mathrm{~h}$ of incubation, the cells were treated with ketamine $(100 \mu \mathrm{M})$ or varied concentrations of hypaconitine $(0.1-2 \mu \mathrm{M})$ or LY294002 $(10 \mu \mathrm{M})$, and cultured for $72 \mathrm{~h}$. This was followed by the addition of $10 \mu \mathrm{l}$ of $5 \mathrm{mg} / \mathrm{ml}$ MTT solution within 4 $\mathrm{h}$, after which the culture medium was changed. Dimethylsulfoxide (DMSO, $200 \mu \mathrm{l}$ ) was added in drops to each well, and the wells were placed on an oscillator for $10 \mathrm{~min}$ to completely dissolve the formazan crystals. The control wells contained culture medium, MTT solution and DMSO only, and were treated same way as the sample wells. Each well was incubated in the dark for $2 \mathrm{~h}$ and absorbance was measured at $570 \mathrm{~nm}$ using synergy II microplate reader. The procedure was performed in triplicate and cell viability was calculated.

\section{TUNEL assay}

This was used to determine the extent of apoptosis in neuronal cells. The isolated neuronal cells were washed with phosphatebuffered saline (PBS) and fixed with ice-cold paraformaldehyde (4\%). Endogenous peroxidase activity was quenched at room temperature within $30 \mathrm{~min}$, and the cells were further permeabilized with $0.1 \%$ Triton X-100 in $0.1 \%$ sodium acetate for $5 \mathrm{~min}$ at $4{ }^{\circ} \mathrm{C}$. The cells were labelled by treating them with TUNEL reaction mixture at $37^{\circ} \mathrm{C}$ for $2 \mathrm{~h}$. Dark brown precipitate was formed on incubating the cells 
with diaminobenzidine substrate (DAB). The number of TUNEL-positive cells was determined using Olympus light microscope. Apoptotic index (A) was calculated as in Eq 1.

$A=(T / C)$

where $\mathrm{T}$ and $\mathrm{C}$ are no. of TUNEL-positive nuclei and total no. of total cell nuclei, respectively

\section{Western blotting}

The cells were washed with PBS and ice-cold radio-immunoprecipitation assay buffer (RIPA) containing protease inhibitor was used to lyse them. The resultant lysate was centrifuged at $12000 \mathrm{rpm}$ for $10 \mathrm{~min}$ at $4{ }^{\circ} \mathrm{C}$, and the protein concentration of the supernatant was determined using BCA assay kit. A portion of total cell protein $(20-30 \mu \mathrm{g})$ from each sample was separated on $12 \%$ sodium dodecyl sulphate (SDS)polyacrylamide gel electrophoresis and transferred to a fixed polyvinylidene fluoride membrane at $110 \mathrm{~V}$ and $90{ }^{\circ} \mathrm{C}$ for $120 \mathrm{~min}$. Subsequently, non-fat milk powder $(3 \%)$ in Trisbuffered saline containing $0.2 \%$ Tween-20 (TBST) was added with gentle shaking at $37{ }^{\circ} \mathrm{C}$ and incubated to block non-specific binding of the blot. The blots were incubated overnight at $4{ }^{\circ} \mathrm{C}$ with primary antibodies for Akt, p-Akt, Bcl-2, caspase- 3 and $\beta$-actin at a dilution of 1:500. Then, the membrane was washed thrice with TBS-T and further incubated with horseradish peroxidase-conjugated goat anti-rabbit IgG secondary antibody for $1 \mathrm{~h}$ at room temperature. The blot was developed using an x-ray film. Grayscale analysis of the bands was performed using ImageJ analysis software (4.6.2). Respective protein expression levels were normalized to that of $\beta$-actin which was used as a standard reference.

\section{Statistical analysis}

Data are expressed as mean \pm SEM $(n=10)$. Statistical analysis was performed using GraphPad prism (6.1). Groups were compared using Duncan multiple test range. Values of $p<$ 0.05 were considered statistically significant.

\section{RESULTS}

Effect of hypaconitine on the viability of neuronal cells

There were only few viable cells in ketaminetreated group. However, cell viability was significantly and dose-dependently increased in hypaconitine-treated groups $(p<0.05$; Figure 1$)$.

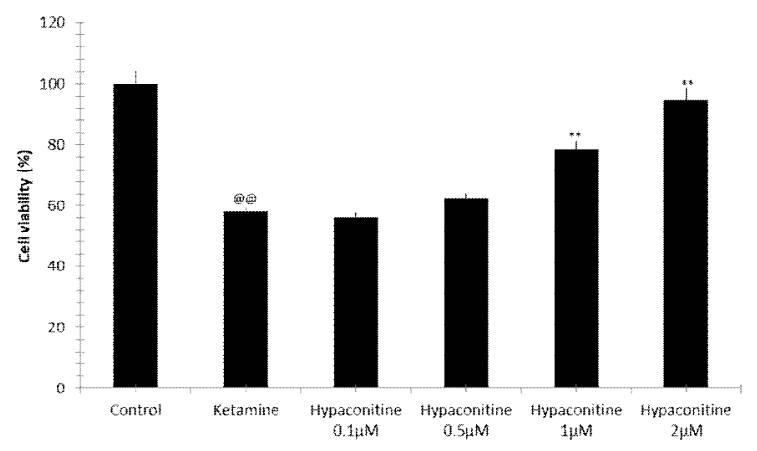

Figure 1: Viability of neuronal cells after treatment with ketamine or varied concentrations of hypaconitine. $@ @<<0.05$, compared with control group; $p<0.05$, compared with ketamine-treated group

\section{Effect of hypaconitine on neuronal cell apoptosis}

As shown in Figure 2, the extent of apoptosis was significantly higher in ketamine-treated cells than in control cells, but treatment with hypaconitine significantly reduced the number of apoptotic cells $(p<0.05)$. However, in the presence of LY294002 (a PI3K-specific inhibitor), the effect of hypaconitine on neuronal cell apoptosis was significantly reversed $(p<0.05)$.

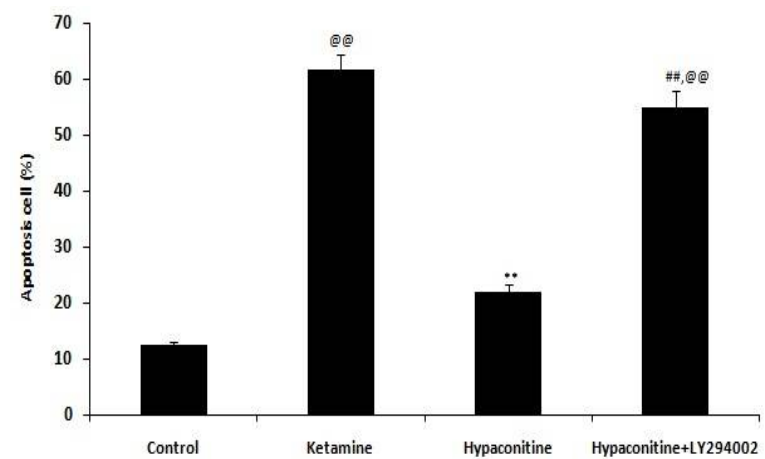

Figure 2: Effect of ketamine, hypaconitine and LY294002 on apoptosis of neuronal cells. ${ }^{\circledR} p<0.05$, compared with control group; ${ }^{\star *} p<0.05$, compared with ketamine- treated cells; ${ }^{\#} p<0.05$, compared with hypaconitine-treated cells

\section{Effect of hypaconitine on the expressions of p-Akt, Bcl-2 and caspase-3}

The expressions of p-Akt and Bcl-2 were significantly down-regulated, and the expression of caspase-3 was significantly upregulated in ketamine-treated neuronal cells, when compared with control group $(p<0.05)$. However, in cells treated with hypaconitine, the expressions of $p$ Akt and Bcl-2 were significantly upregulated, while the expression of caspase-3 was significantly down-regulated $(p<0.05)$. 
Treatment of neuronal cells with hypaconitine in the presence of LY294002 significantly reversed the effect of hypaconitine on the expressions of p-Akt, Bcl-2 and caspase-3 $(p<0.05)$. These results are shown in Figure 3.
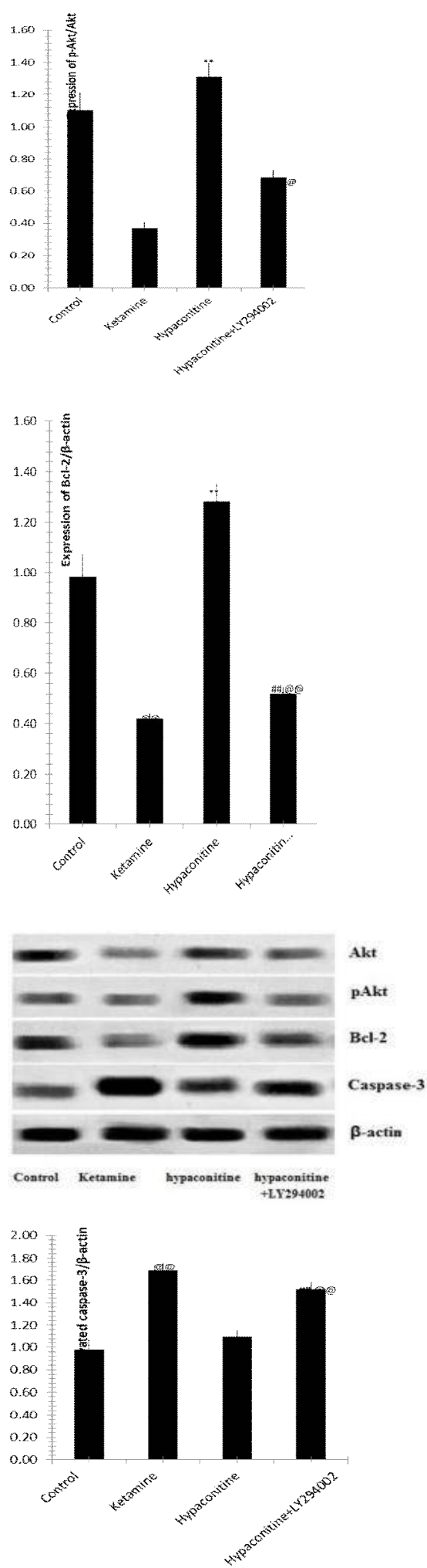

Figure 3: Effect of ketamine, hypaconitine and LY294002 on the expressions of p-Akt, Bcl-2 and caspase-3. @@ $p<0.05$, compared with control group;
${ }^{* *} p<0.05$, compared with ketamine- treated group; ${ }^{\#} p$ $<0.05$, compared with hypaconitine -treated group

Viability of neuronal cells after treatment with ketamine, hypaconitine and LY294002

Ketamine significantly reduced viability of neuronal cells, when compared with control group, but the number of viable cells were significantly increased in the hypaconitine-treated group $(p<0.05)$. However, in the presence of LY294002, the effect of hypaconitine on ketamine-induced decreases in viability of neuronal cells was significantly reversed $(p<$ 0.05; Figure 4).

I

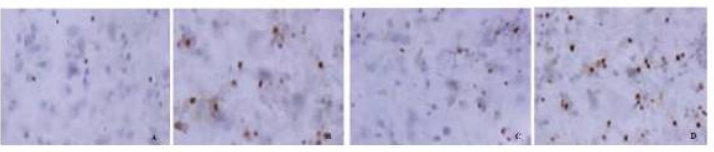

II

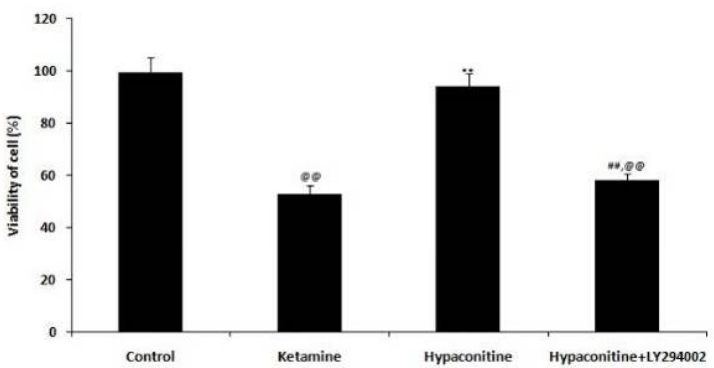

Figure 4: Effect of ketamine, hypaconitine and LY294002 on the viability of neuronal cells. I: TUNEL staining; II: Percentage cell viability. ${ }^{@} p<0.05$, compared with control group; ${ }^{* *} p<0.05$, compared with ketamine- treated group; ${ }^{\#} p<0.05$, compared with hypaconitine-treated group

\section{DISCUSSION}

Ketamine, an analgesic, is widely used for induction of anesthesia during surgery [1]. It is reported to cause neuronal injury in the developing brain [2]. The present study investigated the neuroprotective effect of hypaconitine on ketamine-induced neurodegeneration in brains of neonatal rats, and the underlying mechanism. Ketamine promotes apoptosis in neuronal cells via the downregulation of $\mathrm{p}$-Akt expression and blockage of $\mathrm{N}$-methyl-D-aspartate (NMDA) receptor [18]. In this study, there were only few viable cells in ketamine-treated group, but cell viability was significantly and dose-dependently increased in the hypaconitine-treated groups, an indication that hypaconitine may protect neuronal cells against ketamine-induced neurodegeneration. 
The PI3K pathway plays a key role in the survival of neuronal cells: it activates the phosphorylated form of protein kinase B (p-Akt) [19]. The results of this study showed that treatment with hypaconitine significantly reduced the number of apoptotic cells. However, PI3K-specific inhibitor (LY294002) significantly reversed the effect of hypaconitine on neuronal cell apoptosis. Caspase-3 and $\mathrm{Bcl}-2$ proteins play important roles in the induction of apoptosis [20].

In this study, the expressions of p-Akt and Bcl-2 were significantly down-regulated, while the expression of caspase-3 was significantly upregulated in ketamine-treated neuronal cells, when compared with control group. However, in hypaconitine-treated cells, the expressions of $p$ Akt and $\mathrm{Bcl}-2$ were significantly upregulated, while the expression of caspase-3 was significantly down-regulated. Treatment of neuronal cells with hypaconitine in the presence of LY294002 significantly reversed the effect of hypaconitine on the expressions of $\mathrm{p}$-Akt, Bcl-2 and caspase-3. These results suggest that LY294001, when used in combination with hypaconitine may reverse hypaconitineenhanced viability of neuronal cells.

\section{CONCLUSION}

The results obtained in this study suggest that hypaconitine ameliorates ketamine-induced neuronal injury in neonatal rats via a mechanism involving the $\mathrm{PI} 3 \mathrm{~K} / \mathrm{Akt} / \mathrm{Bcl}-2$ pathway.

\section{DECLARATIONS}

\section{Acknowledgement}

The authors acknowledge the support from China-Japan Union Hospital of Jilin University, Changchun, Jilin, China. This study was financed by China-Japan Union Hospital of Jilin University, Changchun, Jilin, China.

\section{Conflict of interest}

No conflict of interest is associated with this work. The funding organization(s) played no role in the study design; in the collection, analysis, and interpretation of data, in the writing of the report, or in the decision to submit the report for publication.

\section{Contribution of authors}

We declare that this work was done by the authors named in this article and all liabilities pertaining to claims relating to the content of this article will be borne by the authors. The manuscript was written by Junbao Liu. Yubo Hu and Linlin Li collected materials and did statistical analysis. The whole study was designed and supervised by Longyun Li.

\section{Open Access}

This is an Open Access article that uses a funding model which does not charge readers or their institutions for access and distributed under the terms of the Creative Commons Attribution License (http://creativecommons.org/licenses/by/ 4.0) and the Budapest Open Access Initiative (http://www.budapestopenaccessinitiative.org/rea d), which permit unrestricted use, distribution, and reproduction in any medium, provided the original work is properly credited.

\section{REFERENCES}

1. Kurdi MS, Theerth KA, Deva RS. Ketamine: Current applications in anesthesia, pain, and critical care. Anesth Essays Res. 2014; 8(3): 283-290.

2. Wang RR, Jin JH, Womack AW, Lyu D, Kokane SS, Tang $N$, Zou $X$, Lin $Q$, Chen J. Neonatal ketamine exposure causes impairment of long-term synaptic plasticity in the anterior cingulate cortex of rats. Neuroscience. 2014; 268: 309-317.

3. Zuo D, Sun F, Cui J, Liu Y, Liu Z, Zhou X, Li Z \& Wu Y, Alcohol amplifies ketamine-induced apoptosis in primary cultured cortical neurons and PC12 cells through downregulating CREB-related signaling pathways. Sci Rep.2017; 7: 10523.

4. Sun L. Early childhood general anaesthesia exposure and neurocognitive development. Brit J Anaesth. 2010; 105 (Suppl 1): i61-i68.

5. Brambrink AM, Evers AS, Avidan MS, Farber NB, Smith DJ, Martin LD, Dissen GA, Creeley CE, Olney JW. Ketamine-induced neuroapoptosis in the fetal and neonatal rhesus macaque brain. Anesthesiology. 2012; 116(2): 372-384.

6. Alam A, Suen $K C$, Hana $Z$, Sanders $R D$, Maze $M$, Ma $D$. Neuroprotection and neurotoxicity in the developing brain: an update on the effects of dexmedetomidine and xenon. Neurotoxicol Teratol. 2017; 60: 102-116.

7. Almenrader $N$, Colucci $P$, De Castro V, Valeri D, Palmery $M$, Trezza $V$, Campolongo P., Effects of sevoflurane and clonidine on acid base status and long-term emotional and cognitive outcomes in spontaneously breathing rat pups. Gasbarri A, ed. PLoS ONE. 2017; 12(3): e0173969.

8. Mokudai T, Ayoub IA, Sakakibara Y, Lee EJ, Ogilvy CS, Maynard KI. Delayed treatment with nicotinamide (Vitamin B(3)) improves neurological outcome and reduces infarct volume after transient focal cerebral ischemia in Wistar rats. Stroke. 2000; 31(7): 1679 1685.

Trop J Pharm Res, September 2019; 18(9): 1843 
9. Robinson BL, Dumas M, Cuevas E, Gu Q, Paule MG, Ali $S F$, Kanungo J., Distinct effects of ketamine and acetyl I-carnitine on the dopamine system in zebrafish. Neurotoxicol Teratol. 2016; 54: 52-60.

10. Hikino H, Takata H, Fujiwara M, Konno $C$ and Ohuchi $K$. Mechanism of inhibitory action of mesaconitine in acute inflammations. Eur J Pharmacol 1982; 82(1-2): 65-71.

11. Saito $H$, Ueyama $T$, Naka $N$, Yagi J, and Okamoto $T$. Pharmacological studies of ignavine, an aconitum alkaloid. Chem. Pharm Bull. (Tokyo) 1982; 30(5): 18441850.

12. Kimura I, Takada $M$ and Nojima $H$. Aconitine induces bradycardia through a transmission pathway including the anterior hypothalamus in conscious mice. Biol Pharm Bull 1997; 20(8): 856-860.

13. Telang BV and Ng'ang'a JN. Involvement of Central adrenergic mechanisms in the induction of cardiac arrhythmias by aconitine nitrate administered intraventricularly. Indian J Physiol Pharmacol 1975; 19(1): 1-10.

14. Kaneko $R$, Hattori $S$, Furuta $S$, Hamajima $M$, Hirata $Y$, Watanabe $K$, Seno $H$, Ishii $A$. Sensitive analysis of aconitine, hypaconitine, mesaconitine and jesaconitine in human body fluids and Aconitum tubers by LC/ESITOF-MS. J Mass Spectrom. 2006; 41(6): 810-4.

15. Kimura M, Muroi M, Kimura I, Sakai S and Kitagawa I. Hypaconitine, the dominant constituent responsible for the neuromuscular blocking action of the Japanese-sino medicine "bushi" (aconite root). Jpn J Pharmacol 1988; 48(2): 290-293

16. Perlman $R$ and Guideri G. Cardiovascular changes produced by the injection of aconitine at the area of the locus coeruleus in unanesthetized rats. Arch Int Pharmacodyn Ther 1984; 268(2): 202-215.

17. Li T-F, Gong N, Wang Y-X. Ester Hydrolysis Differentially Reduces Aconitine-Induced Anti-hypersensitivity and Acute Neurotoxicity: Involvement of Spinal Microglial Dynorphin Expression and Implications for Aconitum Processing. Front Pharmacol. 2016; 7: 367.

18. Dong C, Rovnaghi CR, Anand K. Ketamine affects the neurogenesis of rat fetal neural stem progenitor cells via the PI3K/Akt-p27 signaling pathway. Birth Defects Res B Dev Reprod Toxicol. 2014; 101(5): 355-363.

19. Koh S-H, Lo EH. The Role of the PI3K Pathway in the Regeneration of the Damaged Brain by Neural Stem Cells after Cerebral Infarction. J Clin Neurosci. (Seoul, Korea). 2015; 11(4): 297-304.

20. Pellegrini M, Strasser A. Caspases, Bcl-2 Family Proteins and Other Components of the Death Machinery: Their Role in the Regulation of the Immune Response. In: Madame Curie Bioscience Database [Internet]. Austin (TX): Landes Bioscience; 2000-2013. 